\title{
Causes and Consequences of Idle Youth in Guatemala
}

\author{
Luis Rene Cáceres ${ }^{1}$ \\ ${ }^{1}$ Independent Researcher, El Salvador \\ Correspondence: Luis Rene Cáceres, 5456 Paseo General Escalón, San Salvador, El Salvador. E-mail: \\ luisrenecaceres@gmail.com
}

Received: October 26, 2020

Accepted: December 12, 2020

Online Published: December 20, 2020

doi:10.5539/ijef.v13n1p61

URL: https://doi.org/10.5539/ijef.v13n1p61

\begin{abstract}
This paper analyzes the causes and consequences of the percentage of the youth population that is not working, in school or in traning, Neets, in Guatemala. The study rests on the estimation of regression equations that explain the percentage of Neet population in terms of variables associated with the labor market; other set of equations were estimated to assess the role that Neets have in the Guatemalan economy. The data employed was taken from the World Bank's World Development Indicators. The results indicate that the percentage of female and male Neets decrease as the credit to the private sector increase; said percentage increases with the increase of the deficit in the trade balance and with the increase in youth unemployment. Another result is that the Neet population exert negative impacts on the employment to population ratio and on the rate of economic growth. These results are augmented by the analisis of the relationships existing between the percentages of Neets and economic growth, the number of homicides and the number of persons that are incarcerated using a cross section of 2010 data from 13 Latin American countries. The results presented in the paper should motivate policy makers in Guatemala and other countries to design and implement policies geared towards preventing that youth become Neets.
\end{abstract}

Keywords: labor market, unemployment, economic growth, credit

\section{Introduction}

This work analyzes the segment of the young population of Guatemala that is Not in Education, Employment, or Training, called Neets.

The existence of Neets in a country constitutes a serious problem from various points of view. On the one hand, Neets reduce the ratio of employed persons to the total population, with adverse consequences on economic growth; furthermore, Neets can give rise to the transmisión of poverty from one generation to the next. Of special importance is the role of Neets in the growth of violence in Latin America, since unemployed youth have been identified as a trigger for violence (Chioda, 2017). Data presented by Chioda (2017) show that in Latin America the number of homicides per 100,000 inhabitants committed by the age group 10 to 14 years was 5 , to increase to 28 in the group 15 to 19 years, and 48.2 in the 20-24 group, to start falling after that age group. It can be seen that it is in the age of the Neets that young people commit the highest number of crimes per 100,000 inhabitants.

Female Neets can give rise to the transmission of gender inequality, given that, in the absence of employment or education, they will be in a weak position to claim their rights and combat abuses. In fact, countries where gender inequality is high also have high percentages of female Neets (Caceres, 2018).

This paper analyzes the phenomenon of the female and male Neet population in Guatemala, based on a sample of data from the period 1990-2018. Previous studies have analyzed the Neet population in several countries with hosehold survey data; this is the first study conducted with time series data of a specif country. After a brief review of the literature, the causes that give rise to this phenomenon are analyzed, as well as the consequences in terms of reductions in economic growth. The work ends with a series of conclusions. The research methodology consists on the estimation of regression equations where Guatemala's percentages of Neet population enter as dependent variables, so as to identify the variables that cause this phenomenon. Other equations are estimated to determine the repercussion that the Neet population exerts on Guatemala's economic growth. 


\section{Review of the Selected Literature}

Reference must first be made to the diagnosis of Neets conducted by de Hoyos, Rogers, and Popova (2015) which comprised 15 Latin American countries. In percentage terms, between 1990 and 2010 the incidence of Neets decreased from 23.4 to 19.3 percent, but in absolute terms, it increased from 16.3 to 18.2 million. The incidence was more marked in rural areas, with 21 percent, higher than 16.8 percent in urban areas, but in absolute values, 13 of the 18.2 million Neets were in urban areas. The authors also reported that 68.6 percent of Neets were female, of which 35.5 percent lived with their parents and were not looking for work. Male Neets represented 31.4 percent of the total and 29.7 percent resided with their parents. In the 15 to 18 -year-old group, the main reason for being in the Neet category was dropping out of school, while in the 19 to 24-year-old group the main reason was the low quality of education. Regarding the role of income distribution, the authors reported that 30.5 percent of young people belonging to the poorest quintile of the income distribution were in a Neet situation, higher than the 6.6 percent of youth belonging to the richest quintile.

Cárdenas, de Hoyos, and Szekely (2016) analyzed the determinants of being a Neet in 18 Latin American countries, with data from 1989 to 2010 . They reported that the variables that reduced the probability that a young person entered the Neet situation were the household income and the fact that the head of the household was employed; this probability increased when the head of the household was a woman. They reported that economic growth had no impact on male Neets, but reduced female Neets. Years of schooling had no impact on male Neets, but the percentage of female Neets tended to fall as their years of schooling increased. GDP per capita had no effect on male Neets but the percentage of female Neets decreased as GDP per capita increased.

Special interest resides in the work of de Hoyos, Gutiérrez Fierros, and Vargas (2016) who pointed out for the case of Mexico, that in the period 1995-2006 there was no association between the percentages of Neets and the homicide rate; however, between 2007 and 2011, a close association was detected between the percentage of male Neets and violence, which had its origin in the repercussions of the global crisis of 2008-2009 on the Mexican economy, which contracted by 6 percent in that period, while exports fell by 6.3 percent (Note 1). The increase in the percentage of male Neets that resulted in 2007-2011 explains a quarter of the increase in violence in those years; another variable that determined the increase in the percentage of Neets was the dropout rate from secondary education, which resulted from the economic recession.

Águila et al. (2015) presented a diagnosis of Neets in Mexico, reporting that the total number of Neets reached a percentage of 28.6 percent in 2010, lower than the 34.1 percent prevalent in 1990. Most Neets were unemployed and characterized by high levels of poverty: 27.0 percent suffered from food poverty, higher than 13.1 percent of young non-Neets. On average, male Neets had 9.4 years of education, and female ones had 8.2 years. 24.3 percent of the Neets dropped out of school because their family did not have enough income, and 74.5 percent of these said they would like to go back to school if they had the resources. Most Neets stated that there were no job opportunities, but 52.8 percent continued to search for work.

The importance of education in the prevention of becoming a Neet is detailed in the study by Arceo and Campos Vásquez (2011) on the determinants of being a Neet in Mexico. These authors show that in the segment aged 15 to 19 years, having reached secondary education reduced the probability of being Neet by 5.1 and 6.7 percent for men and women respectively, while in the segment aged 20 to 24 years, having completed the University education reduced it by 5.6 and 19.1 percent, which shows that education "protects" women more than men from becoming Neet. They also reported for young people between 15 and 19 years old, that if the head of the household had obtained a university degree, the probability that her/his son was a Neet decreased by 9.3 percent, and that of her/his daughter decreased by 17.6 percent.

Other studies on Neets are presented by de Hoyos, Gutiérrez Fierros (2016), and Szekely and Karver (2015).

\section{Methods}

\subsection{Data}

All data was taken from the World Bank's World Development Indicators and comprise the 1990-2018 period, except for the cross section data of Neets in Latin America, that was taken from de Hoyos, Rogers and Popova (2015) and corresponds to 2010. The source of data on homicides per 100,000 inhabitants and on the number of persons incarcerated, was UNDP's Human Development Report 2016.

The average values and standard deviations of the variables are shown in Table 1. 
Table 1. Average values and standard deviations of the variables

\begin{tabular}{lcc}
\hline Variable & Average & Estándar deviat \\
\hline Deficit, imports-exports & 10.07 & 3.73 \\
D(Credit) & 0.63 & 2.27 \\
Female self employment & 55.51 & 4.00 \\
Male self employment & 42.50 & 4.22 \\
Female Neet & 43.77 & 2.76 \\
Male Neet & 7.17 & 1.15 \\
Growth & 3.63 & 1.07 \\
Female youth employ/Population & 32.27 & 1.50 \\
Male youth employ/Population & 72.94 & 2.91 \\
Number of homicide* & 21.78 & 22.47 \\
Number of incarcerated persons* & 263.07 & 96.19 \\
Female Neet 2010 & 27.80 & 7.22 \\
Male Neet 2010 & 11.98 & 2.19 \\
Female youth Unemployment & 6.35 & 1.31 \\
Male youth Unemployment & 4.11 & 0.38 \\
\hline
\end{tabular}

* Per 100,000 inhabitants.

\subsection{Methodology}

All variables were subjected to unit root tests using the ADF test, with results indicating that all were integrated of order 1 at the 1 percent level, except for the male youth unemployment rate, which turned out to be stationary at the 1 percent level. Since the equations to be estimated include variables with unit roots, it was decided to carry out the estimations using the Fully Modified Least Squares methodology of Phillips and Hansen (1990).

\section{Analysis}

\subsection{Neets in the Context of Guatemala's Labor Market}

AS a first approximation to examinig the role of the Neet population on Guatemala's economy it is relevant to assess specific developments in the labor market that are associated with the Neet population, particularly the employment to population ratio and labor productivity. The starting point is the identity that expresses the GDP per capita $\mathrm{Y} / \mathrm{P}$, as: $\mathrm{Y} / \mathrm{P}=(\mathrm{Y} / \mathrm{L})(\mathrm{L} / \mathrm{P})$, where $\mathrm{Y}$ is $\mathrm{GDP}, \mathrm{L}$ is the employed population, and $\mathrm{P}$ is the population of the country in question, $\mathrm{Y} / \mathrm{L}$ is labor productivity and $\mathrm{L} / \mathrm{P}$ is the ratio of employment to population.

Figure lindicates that Guaetmala's labor productivity showed an upward trend from 1990 to 2006, and after that year it has remained practically constant.

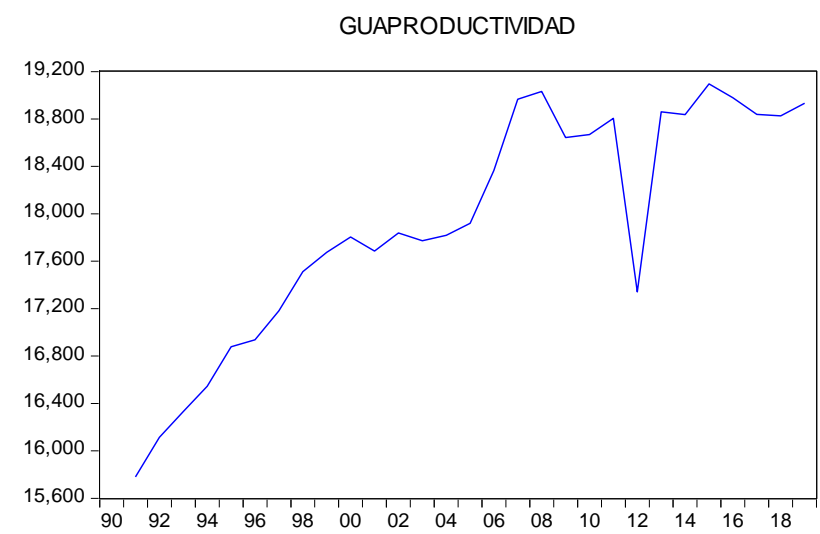

Figure 1. Labor productivity

The stagnation of productivity implies that the impulses to economic growth must originate in the increase in the ratio of employment to population.

Figure 2 shows the trajectories of the female and male L / P ratio. The first one initially shows a slight upward 
trend and begins to fall in 2004, to start to grow again in 2013 but in 2018 its value was around three percentage points lower than the average value between 1990 and 2012. This indicates that a loss of female employment has occurred in Guatemala.The ratio of male employment to population shows a declining trend in the period 1990 2010; it started to recover in 2012, and at the end of the period it reached the early 1990's values.

These ratios are counter-cyclical, that is, female employment tends to increase when male employment falls. This represents the phenomenon of the "additional worker", which consists of women entering the labor market when men experience unemployment, to compensate for the loss of household income; this mechanism has been shown to exist in several Latin American countries (Note 2).

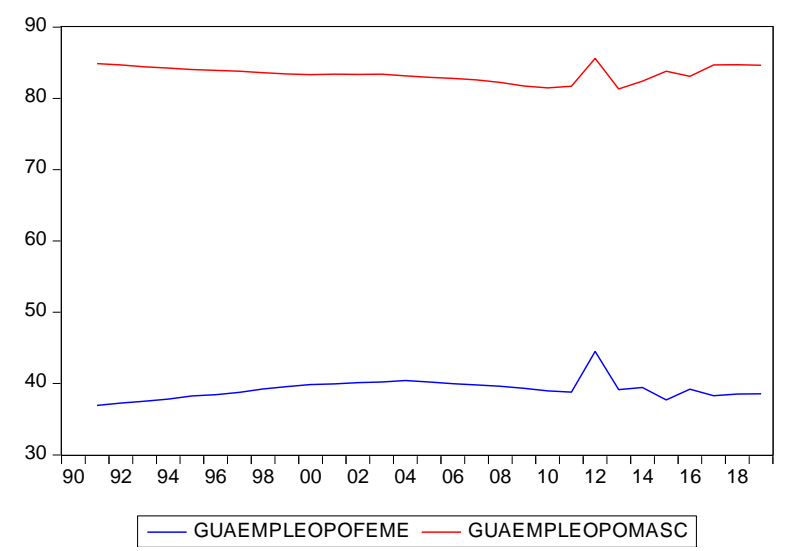

Figure 2. Employment to population ratios, female and male

Figure 3 shows the ratios of female and male youth employment to population (Note 3); it can be seen that they follow the same trends shown in the previous Figure, except that the percentage of female youth employment falls more sharply.

Mackinsey (2017) has argued that, given the declining trend in labor productivity in Latin American countries since the 1980s, their economic dynamism Will depend on employment-to-population ratio, but that this role is going to decline given the aging of the population.

What is observed in Guatemala is that these ratios have downward trends, both of the population in general and in the population between 15 and 24 years old. The absence of young workers from the labor market is more marked, which suggests that youth have "aged prematurely". The question to ask is where do young people go when they leave the labor market?

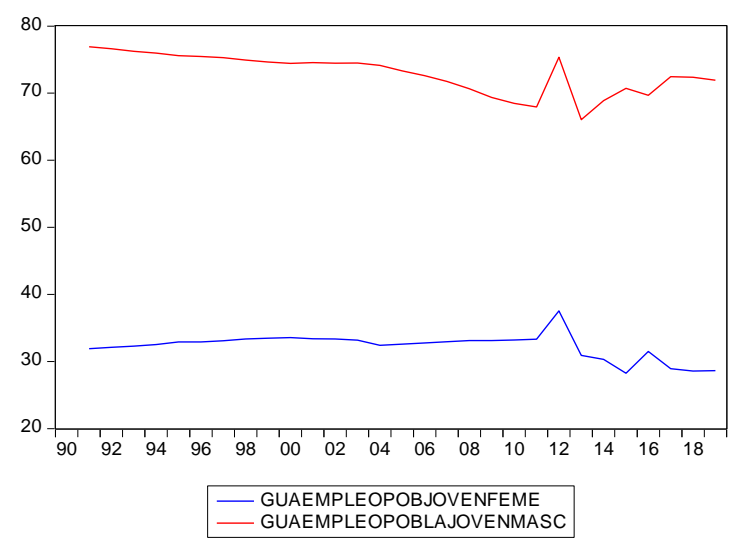

Figure 3. Ratios of female and male youth employment to population

An explanation resides in the persistent emigration flows experienced by Guatemala, mainly after 2000. Emigration impacts the employment-to-population ratio not only because of the people who leave the country, but also because of the role that remittances received by households have in motivating other people to withdraw from the labor market, or to emigrate. 


\subsection{Neets in Guatemala}

There is another destiny for the youth, especially for young women, which lies in not working or studying, that is, in becoming Neets. Guatemala, El Salvador and Honduras have the highest percentage of young women in the situation of Neets in Latin America. Figure 4 shows that the percentage of the female Neet population (Guaninifeme), has increased in the 2009-2017 period, while the percentage of male Neet (Guaninimasc), has remained relatively constant (Note 4).

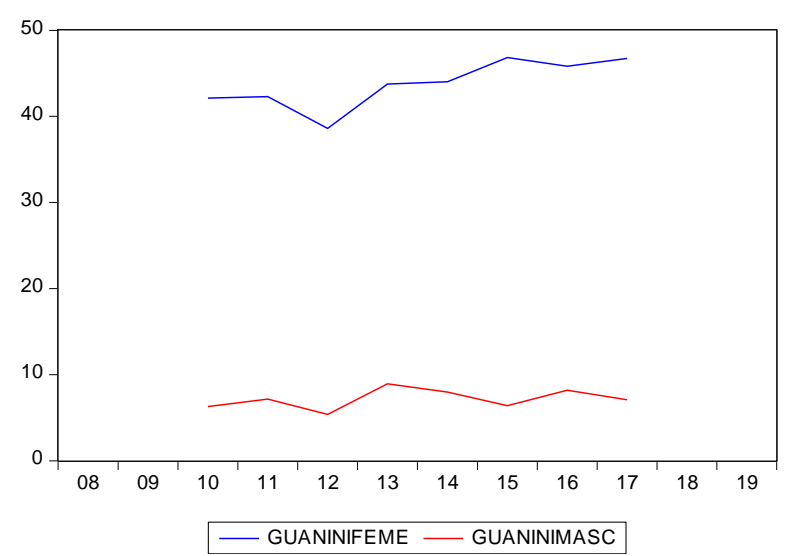

Figure 4. Percentages of female and male Neets

Table 2 presents the percentages of female and male Neets in the Central American countries and Mexico, where it is observed that Guatemala has the highest percentage of female Neets. This percentage shows the gravity of this phenomenon for the economic and social development of Guatemala. It can be assumed that the female Neet population "inherits" low levels of education and poverty to their daughters and sons, resulting in the transmission of poverty from generation to generation.

Table 2. Percentages of the Neet population

\begin{tabular}{lcc}
\hline & Female & Male \\
\hline Guatemala** & 46.74 & 7.09 \\
El Salvador* & 39.14 & 14.52 \\
Honduras* & 42.27 & 11.56 \\
Nicaragua*** & 23.16 & 7.35 \\
Costa Rica* & 21.64 & 14.66 \\
Panamá** & 23.08 & 9.90 \\
México* & 27.71 & 18.30 \\
Belice* & 39.43 & 14.85 \\
\hline
\end{tabular}

Note. $* 2018$ data; $* * 2017$ data; $* * * 2012$ data.

\subsection{Determinants of the Neet Population in Guatemala}

To identify the determinants of the percentages of Neets in Guatemala, reference is made to the work of Caceres (2021a) on youth unemployment in Honduras, that found that its determinants were the credit to the private sector as percentage of GDP, the import tariff, and informality. It is then postulated that these variables have impacts on the percentages of Neets in Guatemala. Table 3 presents equations that express the percentages of female and male Neets in terms of the mentioned variables and others.

In all the equations estimated, the coefficients of the annual increase in credit to the private sector as a percentage of GDP, D(Credit), are negative and significant, indicating the role of credit in reducing the percentage of female Neet, which could be a manifestation of the role of credit to stimulate economic activity. Dao and Qian Liu (2017) have shown the importance of credit in stimulating employment. It should be noted that credit to the private sector has lost dynamism since 2015, as can be seen in Figure 5. 


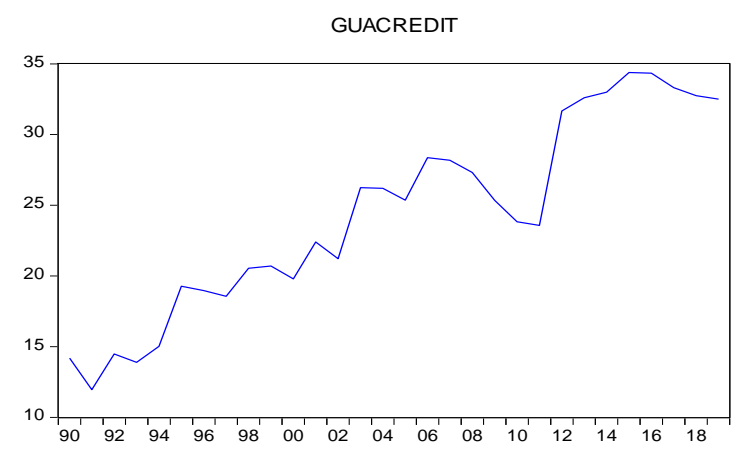

Figure 5. Credit as percentage of GDP and percentage of female Neets

The deficit in the trade account as a percentage of GDP, Deficit, has positive and significant coefficients in all equations. This deficit is a reflection of the contractions of the manufacturing and agricultural sectors resulting from trade liberalization. Figure 6 shows that as agricultural and manufacturing production as a percentage of GDP has fallen, the deficit in the trade account has increased. Santos Paulino (2002) has reported that the main result from trade liberalization in developing countries has been the large deficits in the trade account.

Cárdenas, de Hoyos, and Szekely (2016) argue that the openness of the Latin American economies caused young people to experience difficulties in finding employment in an environment in which small companies were being displaced by large ones (Note 5).

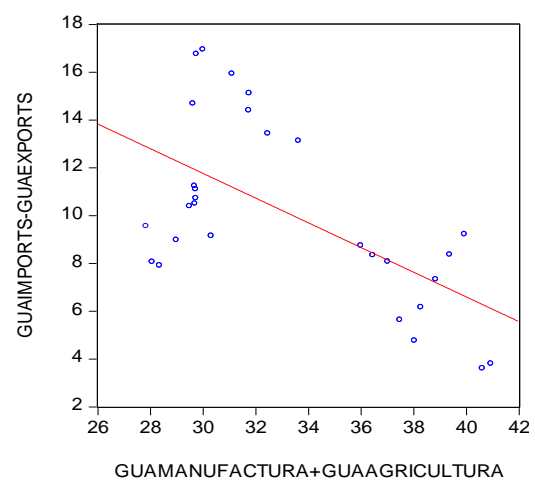

Figure 6. Productive sectors (Guamanufactura+Guaagricultura) and deficit in the trade account (Guaimports-Guaexports)

In the case of El Salvador, Caceres (2021b) has shown that trade liberalization gave rise to the fall of productivity and wage employment and domestic production has been displaced by imports.

Figure 7 shows that as the trade deficit increased, the percentage of female employment in the industrial sector was falling.

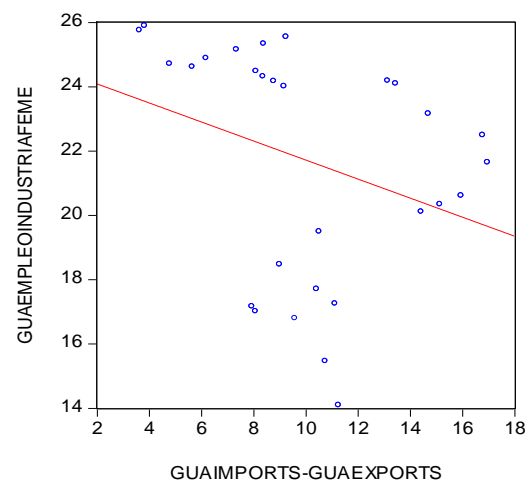

Figure 7. The deficit in the trade account and female employment in the industrial sector

(Guaempleoindustrialfeme) 
It can be seen in equation (1) of Table 3 that the coefficient of female self-employment with a three years lag, which represents female informality, Autofeme (-3), is negative and significant in equations (1) and (2), which indicates that female Neets can transition to informality (Figure 8).

Table 3. Determinants of the porcentajes of Neet population.

\begin{tabular}{|c|c|c|c|c|}
\hline \multicolumn{5}{|c|}{ Percentage of Neets: } \\
\hline & \multicolumn{2}{|c|}{ Female: } & \multicolumn{2}{|c|}{ Male: } \\
\hline & \multicolumn{4}{|c|}{ Equation number: } \\
\hline & $(1)$ & $(2)$ & (3) & (4) \\
\hline \multirow[t]{2}{*}{ Constant } & 109.1125 & 63.5457 & 141.5235 & 75.7288 \\
\hline & $(5.40)$ & $(8.15)$ & $(4.70)$ & $(4.42)$ \\
\hline \multirow[t]{2}{*}{ Deficit } & 0.5228 & 0.9282 & 2.1578 & 1.4528 \\
\hline & $(2.28)$ & $(3.91)$ & $(4.15)$ & $(3.56)$ \\
\hline \multirow[t]{2}{*}{ D (Credit) } & -0.6680 & -0.8562 & -0.4402 & -0.3688 \\
\hline & $(5.11)$ & $(6.19)$ & $(5.27)$ & $(4.77)$ \\
\hline \multirow[t]{2}{*}{ Autofeme (-3) } & -0.6281 & -0.8562 & & \\
\hline & $(5.11)$ & $(6.19)$ & & \\
\hline \multirow[t]{2}{*}{ Feme unemploy(-8) } & -10.4406 & & & \\
\hline & (1.94) & & & \\
\hline \multirow[t]{2}{*}{ Female youth unemployment } & & 1.4814 & & \\
\hline & $(2.64)$ & & & \\
\hline \multirow[t]{2}{*}{ Automasc(-4) } & & & -3.4218 & -2.0806 \\
\hline & & & $(4.50)$ & $(4.08)$ \\
\hline \multirow[t]{2}{*}{ Male unemploy $(-8)$} & & & -4.3768 & \\
\hline & & & $(3.08)$ & \\
\hline \multirow[t]{2}{*}{ Male youth unemployment(-5) } & & & & 1.4525 \\
\hline & & & & $(3.55)$ \\
\hline $\mathrm{R}$ squared & 0.78 & 0.80 & 0.73 & 0.70 \\
\hline
\end{tabular}

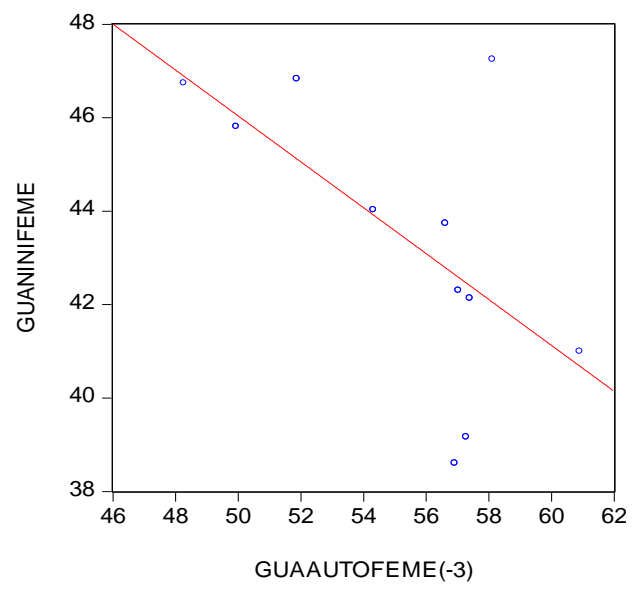

Figure 8. Female self-employment rate lagged three years and percentage of female Neet population

Of special importance is the result shown in equation (1) that the female unemployment rate with a lag of eight years, Female unemployment (-8), has a negative and significant coefficient, which implies that a decrease in female unemployment can be reflected in rising female Neets.

In equation (2) the female youth unemployment rate is introduced instead of the female unemployment rate, which shows a positive and significant coefficient, implying that an increase in female youth unemployment leads to an increase in the percentage of female Neets. This means that there can be a transition or movement of unemployed young women to the female Neet population. The increase in female youth unemployment is related to the increase in the deficit in the trade account, as observed in Figure 9, which denotes an association between economic openness and the percentage of females Neets. 


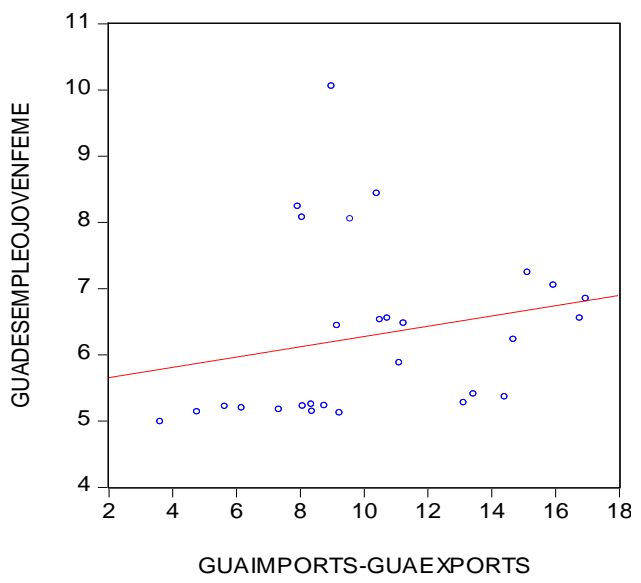

Figure 9. The deficit in the commercial account and female youth unemployment rate

Equations (3) and (4) in table 3 represent the cases of the percentages of male Neets. The coefficient of the male self-employment rate (Automasc), with a lag of four years has a negative and significant coefficient, indicating that self-employment can be a destiny of male Neets; it also indicates that the drop in the percentage of male Neet is associated with the expansion of informality.

The male unemployment rate with a lag of eight years has a negative and significant coefficient which indicates that Neets can transition to male unemployment, that is, a drop in the percentage of male Neet is reflected in an increase in male unemployment.

The male youth unemployment rate with a lag of five years has a positive and significant coefficient, implying that youth unemployment is a source of male Neet.

When comparing the results for female and male Neets, it is observed that the coefficients of the increase in credit are of greater magnitude in the case of female Neets (equations (1) and (2)) than in the male ones (equations (3) and (4)), that is, the expansion of credit would be more effective in reducing female Neets than the male Neets, which could be related to the fact that credit is largely directed to the financing of the commercial sector, where female employment predominates.

The opposite is observed about the trade deficit that shows coefficients of equations (3) and (4) higher than those of equations (1) and (2).

When comparing the coefficients of female and male self-employment, it is observed that the latter is larger than the former, that is, informality could be more attractive for males than for females Neets.

Unemployment seems to be a more important destination for female than male Neets, that is to say, young women are more susceptible than young men to entering a situation of unemployment when they try to get out of the situation of Neets.

On the other hand, the female and male youth unemployment rates have coefficients of almost the same dimension, indicating that they "motivate" youth to enter the situation of Neet to the same degree.

It is necessary to emphasize the transition of Neets towards self-employment, as observed in all the equations, which is especially important given that in Latin American countries self-employment is closely associated with homicide rates (Caceres, 2017).

\subsection{Neets and Economic Growth}

The percentage of Neets have negative impacts on the ratio of youth employment to population, which is a key variable in determining per capita economic growth. Table 4 shows equations that express this ratio in terms of the percentages of Neets. It is observed in equation (1) that the percentage of female Neet has a negative and significant coefficient and the equation explains 68 percent of the variance. In equation (2) the coefficient of the percentage of male Neet is negative and significant. Given that the employment-to-population ratio is a determinant of economic growth, it can be expected that the percentages of Neets will have negative impacts on economic growth. This can be seen in equations (3) and (4) of table 4.

In equation (3) the coefficient for the percentage of female Neets with a 3-year lag has a negative coefficient and, with the qualitative variable Cuali that represents the years of the global crisis 2008-2009, the equation explains 
89 percent of the variance of the economic growth rate. In equation (4), the percentage of male Neet, also with a 3 -year lag, shows a negative and significant coefficient, and the equation explains 83 percent of the variance. It can be seen that the impacts of the percentage of male Neets on the ratio of youth employment to population and on economic growth are of larger magnitude than the impacts exerted by the percentage of female Neets.

These results are evidence that Neets can generate stagnant tendencies to the economy. The implication is that since the percentage of female Neet falls with economic growth (Cárdenas, de Hoyos, \& Szekely, 2016), a vicious cycle of recessionary tendencies can occur, where the growth of the female Neet population deepens economic stagnation, which would increase the female Neet population, and so on.

Table 4. Neets and their impacts on the ratio of employment to population and on economic growth

\begin{tabular}{|c|c|c|c|c|}
\hline \multicolumn{5}{|c|}{ Dependent variable: } \\
\hline & Youth Female/ Population & Youth Male/ population & Growth & Growth \\
\hline & \multicolumn{4}{|c|}{ Equation: } \\
\hline & $(1)$ & $(2)$ & $(3)$ & $(4)$ \\
\hline \multirow[t]{2}{*}{ Constant } & 66.1548 & 86.7684 & 13.0879 & 7.3977 \\
\hline & $(6.53)$ & $(19.72)$ & $(3.98)$ & $(4.87)$ \\
\hline \multirow[t]{2}{*}{ Cuali } & & & 3.6948 & 2.6087 \\
\hline & & & $(6.18)$ & $(4.07)$ \\
\hline \multirow[t]{2}{*}{ Female Neet } & -0.7796 & & & \\
\hline & $(3.42)$ & & & \\
\hline \multirow{2}{*}{ Male Neet } & & -2.231 & & \\
\hline & & $(3.71)$ & & \\
\hline \multirow[t]{2}{*}{ Female Neet $(-3)$} & & & -0.2217 & \\
\hline & & & $(2.94)$ & \\
\hline \multirow[t]{2}{*}{ Male Neet (-3) } & & & & -0.5511 \\
\hline & & & & $(2.7)$ \\
\hline $\mathrm{R}$ squared & 0.68 & 0.71 & 0.89 & 0.83 \\
\hline
\end{tabular}

\subsection{Monitoring of the Percentages of Neets in Guatemala}

Given the importance of preventing youth from ending up in a Neet situation, it is especially important to carry out periodic exercises to analyze the status of youth in the context of their participation in the labor market. It is considered that the monitoring of indicators related to youth unemployment, and especially to the percentages of Neets, would help maintain the concern and attention of society and governments to this problem. Table 5 below presents a series of indicators that can be analyzed at annual meetings of government, civil society, private sector, labor unions, and youth organizations, to measure progress towards the elimination of the phenomenon of the Neets.

The importance that youth promote the creation of such mionitoring mechanism, and in general terms that youth mobilize actions in order that more attention be given to their particular situation, cannot be overstressed; youth should overcome its own inertia, and that of policy makers, to avoid ending as Neets or in a caravan. Youth must not let its future be determined by greed and avarice of the economic elites. The response of society and the political system to the needs of youth constitute a test of the sincerity of the moral discourses aired by different groups of society.

Table 5. Monitoring of indicators on the participation of young people in the labor market.

\begin{tabular}{ll}
\hline & Baseline \\
\hline Indicators: & \\
Spending on education (\% of GDP) & \\
Health expenditure (\% of GDP) & \\
Secondary education coverage & \\
Tertiary education coverage & \\
Preschool education coverage & \\
Percentage of female Neet & \\
Percentage of male Neet
\end{tabular}


Maternal mortality

Infant mortality

Infant morbidity

Social security coverage

Percentage of persons that receive pensions

Female youth unemployment rate

Male youth unemployment rate

Female and male self-employment rates

Scores on quality of education tests

Adolescent fertility rate

Dropout rates

Number of homicides

Number of persons in jail

Number of femicides

Number of women subjected to violence at home

Number of assaults against women

Number of seats occupied by women in Congress

Number of women occupying positions of Ministers in the Executive branch

Number of gender discrimination in employment cases

Number of female students enrolled in science and technology college careers

Emigration rate

Number of caravans

Investment rate

Trade account deficit

Domestic savings rate

\subsection{Neets in Latin America}

This section analyzes th economic and social repercussions of Neets in a cross-section of 2010 data from 13 Latin American countries, taken from de Hoyos, Rogers, and Popova (2015). It can be seen that the percentage of female Neet has a negative association with the ratio of female employment to population, as shown in Figure 10. This is additional evidence that the female Neet is an obstacle to economic growth in the Latin American countries.

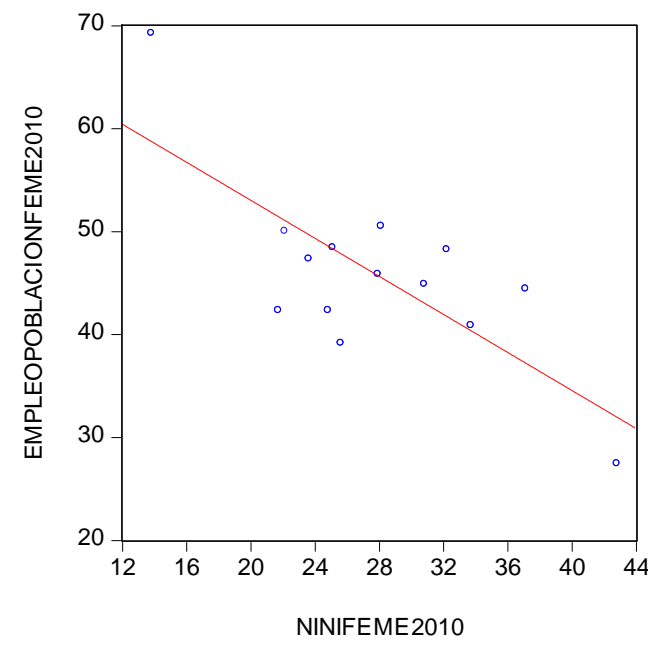

Figure 10. Percentage of female Neets (Ninifeme2010), and ratio of female employment to population

The porcentaje of the female Neet population also has a negative association with the economic growth rate corresponding to 2010 (Figure 11). 


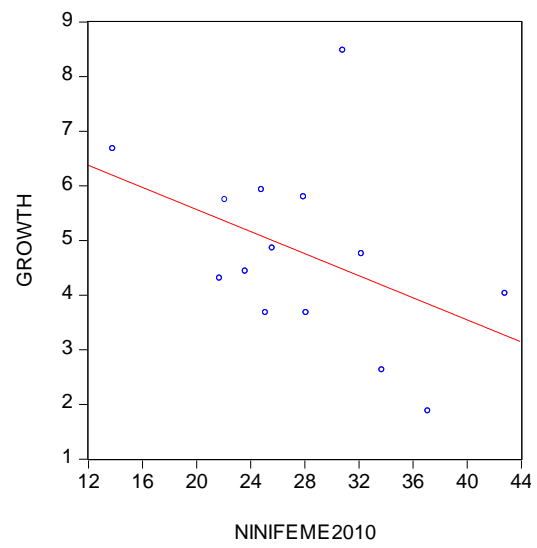

Figure 11. Percentage of female Neets and economic growth rate

It should be noted that, by increasing the national level of education in a given country young women would have better opportunities to successfully enter the labor market, given the evidence that youth chances of having employment increases with her/his leve lof education (Scarpetta, Sonnet, \& Manfredi, 2010). This explains the negative relationship between the percentage of the population that has completed secondary education and the porcentaje of female Neets (Figure 12). As well, their chances of falling into unemployment decreases with having higher levels of education (Azkenazy, Chevalier, \& Erhel, 2015).

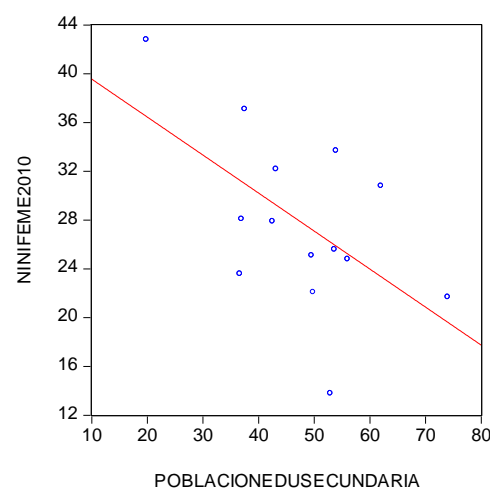

Figure 12. Percentage of the population that has completed secondary education (poblacionedusecundaria) and the percentage of female Neets

Regarding the quality of education, it is observed in Figure 13 that the average scores of the Latin American countries in third grade reading, obtained in the Third Regional Evaluation of the Quality of Education in Latin America, (TERCE, 2016), has a negative relationship with the corresponding percentages of female Neets. In other words, quality of education enables young women to find employment. The results of Lloyd and Clark (2000) should be noted in the sense that increasing the quality of education leads to a reduction in the school dropout rate.

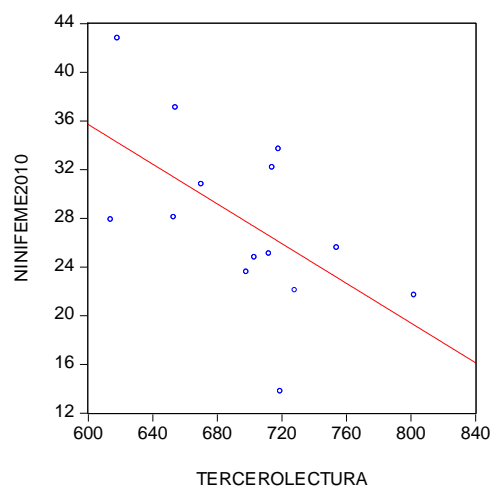

Figure 13. Third-grade reading scores (Tercerolectura) and the percentage of female Neet 
There is evidence that in the Latin American countries the quality of education increases with increasing public expenditures on education (Caceres, 2018). Therefore, there is a negative relationship between spending on education and the percentage of female Neets, as shown in Figure 14:

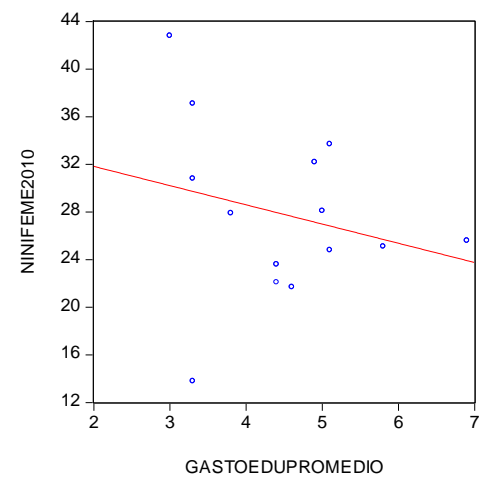

Figure 14. Expenditure on education as percentage of GDP. average 2008-2010, (gastoedupromedio) and the percentage of female Neet

The equation corresponding to Figure 14 is:

Percentage of female Neet $=37.6822-17.0706$ CualiPeru+ 11.3035CualiHonduras -2.0865 Education Expenditure

R squared $=0.67$

Where the qualitative variables CualiPeru and CualiHonduras represent the respective countries.

It should be emphasized that the percentage of female Neets is a determinant of the homicide rate per 100,000 people in the Latin American countries, as shown in Figure 14 (Note 6).

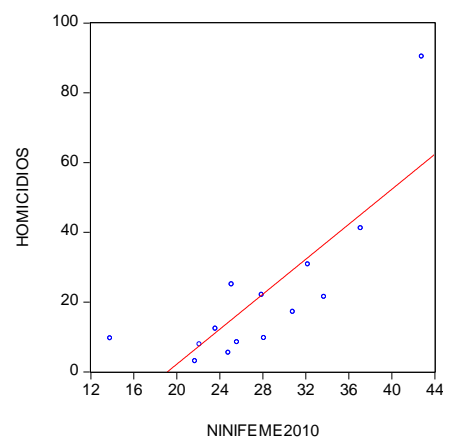

Figure 15. Percentage of female Neets and homicide rates per 100,000 inhabitants (Homicidios)

Given that the percentage of Neets decrease as the quality of education increases (Figure 13), there is an association between the quality of education, measured as the test scores on sixth grade mathematics, and the numebr of homicides, as shown on Figure 16.

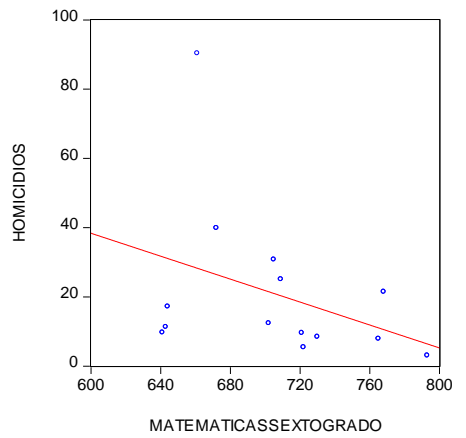

Figure 16. Country Scores on sixth grade mathematics (matematicassextogrado) and numer of homicides per 100,000 people 
Figure 14 showed he existence of a negative relationship between spending on education as a percentage of GDP and the percentage of female Neet, (Figure 14), thus it can be expected that there is a negative association between spending on education and the number of homicides per 100,000 persons, as seen on Figure 17.

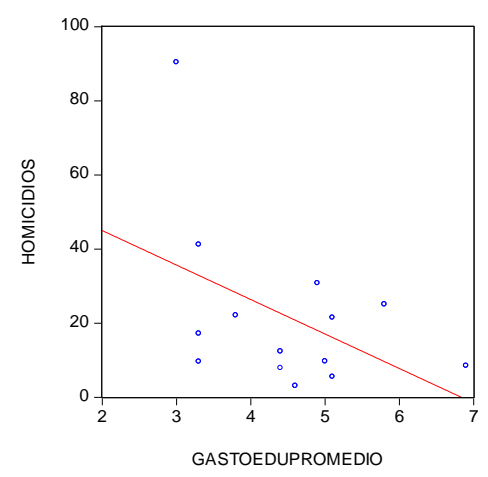

Figure 17. Education expenditures as percentage of GDP and number of homicides per 100,000 persons

It can be expected that there Will be an association between the number of incarcerated people and the spending on education. An estimated equation for the number of incarcerated people in terms of average spending on education and the qualitative variables CualiBrasil, CualiCostaRica, and CualiElSalvador, which represent the cases of Brazil, Costa Rica, and El Salvador respectively, shows that the coefficient of spending on education is negative and significant, and the equation explains 66 percent of the variability of the number of people incarcerated per 100,000 population:

Number of people incarcerated $=420.9088+117.0656$ CualiBrasil +216.9106 CualiCosta Rica
(4.92)
(2.96)

+ 217.7598CualiElSalvador - 43.5136Expenditure education

R squared $=0.66$

This equation shows that if spending on education increases by one percentage point, the number of incarcerated people would fall by 43.51 per 100,000 inhabitants in the respective country. That is, 66 percent of the determination that a person in a Latin American country is in jail is explained by the respective national spending on education as a percentage of GDP; when this expenditue is low, a greater number of people per 100,000 inhabitants will be held in jail.

These results reveal the importance of increasing tax revenues to increase the quality of education and, thus, reduce the percentages of Neets and, therefore, reduce violence and increase economic growth.

The negligence of a government to increase public spending on education, violates the right to education established in the Universal Declaration of Human Rights, and in fact, "pushes" to jail young people who have not had access to good schools, either because their parents did not have good jobs, or because in their childhood their parents experienced unemployment, or because they belong to categories of class, ethnic group, or region of residence, whose members are marginalized.

Low spending on education can be seen as a result of opposition from high-income groups to tax increases, arguing that higher taxes would discourage investment and the business climate; but in reality, what undermines investment and the business climate is low spending on education.

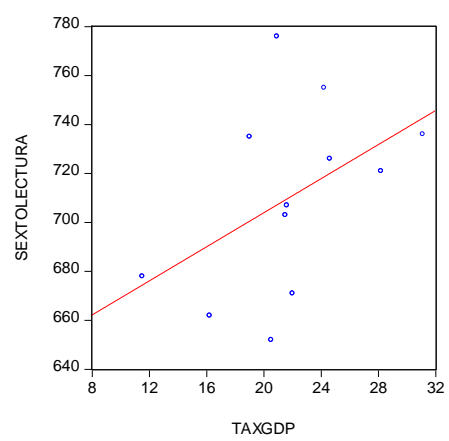

Figure 18. Tax revenues as percentage of GDP and Scores on sith grade Reading 
Figure 18 shows that as tax revenues as percentage of GDP increases the scores on sixth grade Reading increases. This means that increasing tax effort, which is notoriously low in Latin American countries, would contribute to increasing the quality of education, to reduce the number of homicides and of persons in jail.

Of particular interest is the relationship shown on Figure 19, that indicates that, for the case of 9 Latin American countries, that their per capita taxes paid in 1870 have a negative association with the 2010 percentage of female Neets (Note 7).

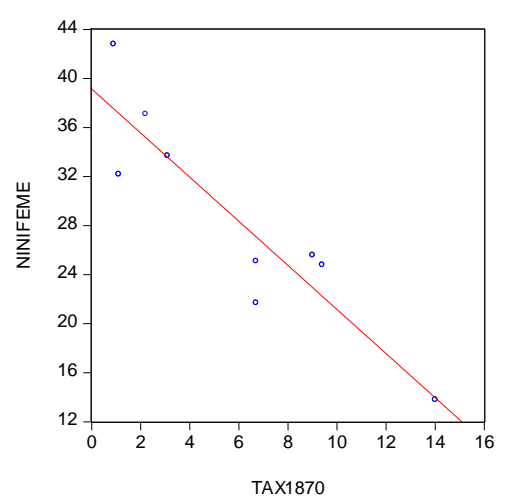

Figure 19. Per capita taxes país in 1870 and 2010 percentages of female Neets

It must be pointed out that the Universal Declaration of Human Rights, establishes in its article number 26 that:

\section{Every one has the right to education.}

The existence of Neets in the Latin American countries can also be associated with the female labor participation; Figure 19 shows that as the ratio of female to male employment increases the percentage of female Neets decrease. It can be assumed that as women increase, their participation in the labor market their income, as well as their capacity to make decisions regarding their household, would increase relative to that of their partners, which would result in guarding that daughters and sons do not droping ut of school and so avoiding becoming Neets.

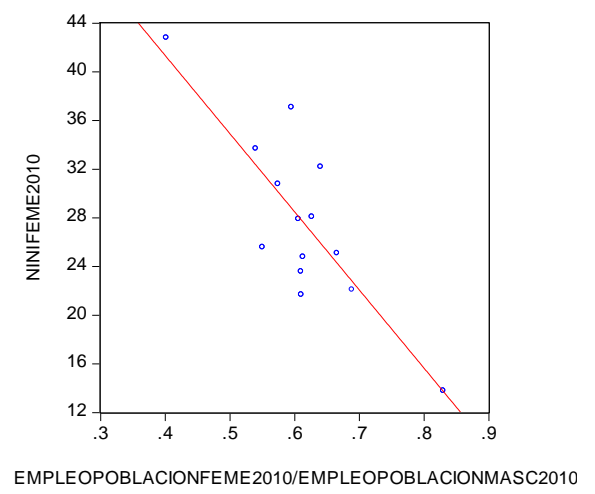

Figure 19. Ratio of female to male employment and percentage of female Neets

\section{Conclusions}

Of particular importance are the drop in the female and male employment to population ratios, both corresponding to youth and the adult population, which has negative repercussions on Guatemala's economic growth. Young people and adults are withdrawing from the labor market in Guatemala. This is a trajectory that is observed in developed countries as a result of the aging of the population, but the Guatemalan population is mostly very young.

The explanation lies in part in emigration, which has become the option of necessity in the face of unemployment. Another explanation is the high percentage of the young population that neither studies or works, especially the female population. Almost half of the young female population, who should be in the best conditions to contribute to the development of their country and their families, are inactive. This means an immense loss of human capital for Guatemala, and a tragedy for the young people who enter this situation. 
The results showed that the percentage of female Neets lowers the ratio of employment to population; other estimated equations showed that the percentages of female and male Neets had negative impacts on economic growth.

Regarding the explanation of the existence of Neets, the econometric estimates showed that, in the first place, trade deficits have been an important determinant, mainly of female Neets. Evidence was also found that lagged female and male youth unemployment rates had impacts on increasing the Neet population.

Given its importance, the analysis of the Neet population was extended to the case of a cross-section of 2010 data from 13 Latin American countries. This analysis revealed that at the regional level, the female Neet population decreases economic growth, and exerts a positive impact on the growth of the homicide rate per 100,000 inhabitants. Related to this last point evidence was reported that the Neet population has a positive association with the number of people in jail.

Faced with unemployment, young people hace three avenues: emigration, crime, or becoming a Neet. These three routes have been present in Guatemala in the last decades as responses to job losses and unemployment resulting, in the first place, from trade liberalization. This is the result reported by McMillan and Rodrik (2011) in their study of Latin America that found that the liberalization of foreign trade was so indiscriminate that there was a transfer of quality employment towards low-quality employment sectors and towards unemployment. These authors point out that:

"We have noted above the costs that premature de-industrialization has on economy-wide productivity. Import competition has caused many industries to contract and release labor to less-productive activities, such as agriculture and the informal sector. One important difference among countries may be the degree to which they can manage downsides. A notable feature of Asian-style globalization is that it has had a two-track nature: many import-competing activities have continued to receive support, while new, export-oriented activities were spawned" (p. 75).

These authors found that the largest countries in Latin America were able, in the face of openness, to retain their workforce in high-productivity sectors:

"When we compute a regional average that sums up value-added and employment in the same sector across countries, giving more weight to larger countries, we get the result.... that the negative structural change component turns very slightly positive in Latin America, indicating that labor flows in the larger Latin American countries have not gone as much in the wrong direction as they have in the smaller ones" (p. 68).

This result highlights, once again, the importance of economic integration for the Central American countries.

How to overcome this situation is the logical and necessary question. An essential measure must be considered, which is to eliminate the excessive opening of the economy that has had no other result than the destruction of quality jobs, economic stagnation, and the loss of tax revenues. This implies increasing tariffs on imported luxury goods, as well as on those that displace national production, particularly in the manufacturing sector.

An area that can be of value is to develop actions conducive to changing the attitudes of youth. This would imply campaigns conducted by teachers and school principals, as well as by business leaders and media outlets, with view towards promoting the recognition by youth that dropping out of school has a high personal cost. Similar campaigns should be develped to prevent early marriage and girls pregnancy. But more important is a change of attitudes by the public and private sectors so that both adopt a common ground around objectives of nation building, so as to create a socio-economic system where the equality of opportunities prevails in all corners of the country. This would implied constructing the channels to carry out dialogues among different sectors, and agreeing on a fiscal pact that would enable destining higher sums of resources to the social sectors.

It should be borne in mind that the now developed countries, especially the "Asian Tigers", never put into effect the policies included in the "Washington Consensus", as Stiglitz (2003) has pointed out. An extensive literature has pointed out that now developed countries sought industrialization through tariff and other means of protection (Chang, 2002). The purpose of these countries was to build a strong state that would be sustained by the power of the economy (Note 8).

A point that should be emphasized is that spending on education has negative relationships with the percentage of female Neet, with the homicide rate, and with the number of people who are in jail. The key variable in this purpose is the fiscal weakness; in fact, Guatemala has the lowest fiscal effort, as well as the lowest spending on education as a percentage of GDP, of the Latin American countries,

The results of low spending on education can be seen in the scores of the quality of education tests in Latin 
American countries carried out in 2013 as reported by TERCE (2016), in which Guatemala as well as Honduras and Nicaragua, obtained the lowest scores on the third and sixth-grade tests in reading and mathematics. This has implications for economic growth given the evidence that there are positive relationships between these scores and the rate of economic growth, that is, countries with a better quality of education tend to grow at higher rates than countries with low quality of education (Hanushek \& Woessmann, 2009; Cáceres, 2018).

Low spending on education can be associated with the reluctance to increase tax revenues by the high-income segments of the population. But this opposition, given the results shown in this paper, has been a true "backfire", since the costs of violence more than exceed the additional tax revenues required to increase spending on education.

Another measure of value is the establishment of national networks of daycare centers with national coverage, which would allow young mothers to continue their studies or enter the labor market. The positive repercussions of low-cost childcare on economic stability and family income have been described for several countries by various authors (Tsounta, 2006). This measure would also contribute to increasing female labor force participation, with positive impacts on economic growth. Ostry et al. (2018) have shown the significant increases in economic growth that are obtained by increasing female participation.

It should be noted that Rodgers (1994) found that the main determinant of the incidence of poverty in single mothers head of the household was their low level of education, and that the creation of networks of low-cost nurseries contributed substantially to their having time to continue their studies and increase their skills.

In this sense, it is important the establishment of flexible education facilities targeted to help Neets obtain diploma or certificates that would enable them to reenter the labor market.

A similar argument can be made about conditional cash transfer programs that have led to positive results in several countries, due to their role in combating the school dropout rate. These programs have been effective in reducing domestic violence in Mexico (Angelucci, 2007), and, due to their role in reducing school dropouts, they have an impact on reducing crime (Ayers, 1998).

It has also been shown that children who have been beneficiaries of conditional grants programs are more likely to graduate from high school than those who have not participated in these programs (Parker \& Vogl, 2018; Araujo et al., 2018 ).

Given the increase in unemployment due to the covid pandemic, it has become especially important to resort to emergency job creation programs. The World Bank (Schwartz, Andres, \& Dragoiu, 2009) has recommended the design and execution of emergency infraestructura programs to confront the rise in unployment resulting from the 2008-2009 crisis.

It should be emphasized that it is not valid to justify the low attention to social development with the argument that the countries do not have the means to carry out large social public expenditures. Easterlin (2013) has pointed out that in 1883 Germany introduced health insurance, in 1884 insurance for accidents at work, and 1889 the public pension system. He adds that in those years the German GDP per capita was 3,200 dollars, in 2005 prices, and that most developing countries, except those of Sub-Saharan Africa, currently exceed that amount. In Latin American countries there are only 4 countries whose GDP per capita is below $\$ 3,200$ : Honduras, Nicaragua, Haiti, and Bolivia.

The opposition to increasing taxation can be associated with what ECLAC (2018) has called the "culture" of privilege and abuse exercised by economic power groups, who assume that they have inherited a "brand" of privilege acquired since colonial times, that allows them to use the state for their own interests.

This is a case of myopia because if public expenditures for education had increased in the past, the Guatemalan economy would have a much larger dimensions today than the current one, which would imply higher profits for companies and reductions in Neets and violence.

This model of underdevelopment has a counterpart in the great majority of the population that experience poverty, exclusion, and irregular emigration. That is to say, the economy of abuse coexists, generates, and propagates the Economy of Cruelty, the latter term coined by Paul Krugman (2020), and which is of an everyday nature in Central America.

The Covid19 crisis has caused a new social scenario that demands a substantial increase in tax collection and allocates greater amounts of resources to the social sector. The crisis of the pandemic should be the starting point of a new development model that relies on investment in people, which has historical support in the experience of developed countries, and especially of the "Asian Tigers". Easterlin (1981) has presented historical evidence 
that social development precedes economic development, and that economic development takes off when society places the same importance on education as it does on religion.

Of course, the difficulties in increasing tax revenues must be recognized. The first step to follow can be to convene a national dialogue to build consensus regarding the additional tax revenues goals that are required to promote social investment, and the destination that would be given to such resources.

The dialogue should also include the design of a transparency and accountability system that would allow verifying that the destination and amounts of the resources were executed according to schedule. Within social investments, special importance should be given to education and health. The pandemic has highlighted, on the one hand, the weakness of the health system and the of social protection network, and on the other hand, the determining role of social class in infection and survival. This represents a violation of the right to life, stipulated in article three of the Universal Declaration of Human Rights: Everyone has the Right to Life, to Liberty.

The foregoing implies the necessity to redesign and modernize the social protection system, and the neccesity to carry out national dialogues that would converge to implementing changes to the constitution of the Republic so as to guarantee, with a human rights approach, attention to education and health, as well as gender equality, and also guarantee the availability of tax resources to make these purposes attenable.

The worst outcome of the pandemic could be that lessons were not learned from the weakness of an economy that is not based on equality of oportunities and that operates within the framework of privilege, and worse yet, that the same structure continues in operation after the crisis.

In the tasks of dialogue leading to the design of a new economic model, special importance should be given to the recognition that the Guatemalan population is 50 percent indigenous in nature and, as is well known, represents the most marginalized and excluded segment of the population. And therefore, special attention should be directed to this population, to make long due justice and make reality their human rights prevail, and eradicate the bloody inheritance of colonial times, so that the indigenous population achieves its economic and social development, in a framework that guarantees continuity of their culture, of their languages, and, especially, of their ancestral religions.

There are other segments of the population that can be viewed as Neets and that deserve the same attention as that given to young Neets; these are the elderly and persons with disabilities, who still wait that justice be done.

Guatemala has a lot going for it, its people in the first place, abundant natural resources, and its national currency so that it can go from tough times to times of justice, so as to comply with Psalm 104: People go out to their work and to their labor until evening.

\section{References}

Aguila, E. et al. (2015). Pobreza y Vulnerabilidad en México: El Caso de los Jóvenes que no Estudian ni Trabajan. Estudios Económicos, 41, 3-49. https://doi.org/10.24201/ee.v30i1.21

Angelucci, M. (2007). Love on the Rocks: Alcohol Abuse and Domestic Violence in Rural Mexico. IZA Discussion Paper no. 2706. https://doi.org/10.2202/1935-1682.1766

Araujo, M. C. et. al. (2018). Se Mejora la Escolaridad con Becas de Mayor Monto? La Evidencia de las Localidades Urbanas de Mexico. Working paper number 8777, Washington DC, Banco Interamericano de Desarrollo.

Arceo, E. O., \& Campos, V. R. M. (2011). Quienes son los Ninis en México? Working paper number 8, El Colegio de México.

Ayres, R. L. (1998). Crime and Violence as Development Issues in Latin America and the Caribbean. Washington DC, World Bank. https://doi.org/10.1596/0-8213-4163-4

Azkenazy, P., Chevalier, M., \& y Erhel, M. (2015). Okun's law Differentiated by Education. Centre Pour la Recherche Economie et Ses Applications, paper 1514.

Caceres, L. R. (2013). Labor Market Participation in Latin America, 2000-2008. Journal of Developing Areas, 47(1), 241-261. https://doi.org/10.1353/jda.2013.0011

Caceres, L. R. (2017). Stylized Facts about Happiness and Violence in Central America. Journal of Business Diversity, 17, 38-78.

Caceres, L. R. (2018). Hechos Estilizados Sobre la Calidad de la Educacion en America Latina. Unpublished.

Caceres, L. R. (2021a). Youth Unemployment and Underdevelopment in Honduras. Unpublished. 
Caceres, L. R. (2021b). Productividad Laboral in El Salvador. To be published in Revista de la Cepal.

Cárdenas, M., de Hoyos, R., \& Szekely, M. (2016). Idle Youth in Latin America: A Persistent Problem in a Decade of Prosperity. Economia, 5, 1-40.

CEPAL. (2018). La Ineficiencia de la Desigualdad. Santiago de Chile, CEPAL.

Cerrutti, M. (2000). Economic Reform, Structural Adjustment and Female Labor Force Participation in Buenos Aires, Argentina. World Development, 28. https://doi.org/10.1016/S0305-750X(99)00163-1

Chang, H. J. (2002). Kicking Away the Ladder. London: Anthem Press.

Chioda, L. (2016). Stop the Violence in Latin America. Washington DC, World Bank.

Dao, M. C., \& Liu, L. Q. (2017). Finance and Employment in Developing Countries: The Working Capital Channel. IMF working paper 17/189. https://doi.org/10.5089/9781484314197.001

De Hoyos, R., Fierros, C. G., \& Vargas, J. V. (2016). Idle Youth in Mexico. Trapped Between the War on Drugs and Economic Crisis. Working paper number 7558, World Bank, Washington DC. https://doi.org/10.1596/1813-9450-7558

De Hoyos, R., Rogers, H., \& Popova, A. (2015). Out of School and Out of Work: A Diagnostic of Ninis in Latin America. Working paper number 7548, World Bank, Washington DC. https://doi.org/10.1596/1813-9450-7548

De Hoyos, R., Rogers, H., \& Szekely, M. (2016). Out of School and Out of Work, Risks and Opportunities for Latin American's Ninis. Working paper, Washington DC, World Bank. https://doi.org/10.1596/1813-9450-7548

Easterlin, R. (1981). Why Isn't the Whole World Developed? The Journal of Economic History, 41. https://doi.org/10.1017/S0022050700042674

Hanushek, E. A., \& Woessmann, L. (2009). Schooling, Cognitive Skills and the Latin American Growth Puzzle. Working paper 15066, Cambridge Massachussetts NBER. https://doi.org/10.3386/w15066

Ho, P. S. (2005). Distortions in the Trade Policy for Development Debate: A Re-examination of Friedrich List. Cambridge Journal of Economics, 29. https://doi.org/10.1093/cje/bei024

List, F. (1991). The National System of Political Economy. Fairfield, NJ, Augustus M. Kelley.

Lloyd, C., \& Inthia, W. C. (2000). The Effects of Primary School Quality on School Drop Out Among Kenyan Girls and Boys. Comparative Education Review, 44. https://doi.org/10.1086/447600

Mckinsey Global Institute. (2017). Where will Latin America's Growth Come from? Discusion document.

McMillan, M., \& Rodrik, D. (2011). Globalization, Structural Change and Productivity Growth. Working paper number 17143, NBER. https://doi.org/10.3386/w17143

Ostry, J. D., Alvarez, J., Espinoza, R., \& Papageorgiou, C. (2018). Economic Gains from Gender Inclusion: New Mechanisms, New Evidence. Staff Discussion Note 18/06, International Monetary Fund. Washington DC. https://doi.org/10.5089/9781484337127.006

Parker, S. W., \& Vogl, T. (2008). Do Conditional cash Transfers Improve Economic Outcomes in the Next Generation? Evidence from Mexico. Working papers 24303, NBER.

Parker, S., \& Skoufias, E. (2004). The Added Worker Effect Over the Business Cycle: Evidence from Urban Mexico. Applied Economics Letters, 11. https://doi.org/10.1080/1350485042000235693

Paz, J. (2009). El Efecto del Trabajador Adicional: Evidencia para Argentina (2003-2007). Cuadernos de Economía, 46. https://doi.org/10.4067/S0717-68212009000200005

Phillips, P. C. B., \& Hansen, B. E. (1990). Statistical Inference in Instrumental Variables Regressions with I(1) Processes. Review of Economic Studies, 57. https://doi.org/10.2307/2297545

Santos, P. A. (2002). The Effects of Trade Liberalization in Imports in Selected Countries. World Development, 30. https://doi.org/10.1016/S0305-750X(02)00014-1

Scarpetta, S., Sonnet, A., \& Manfredi, T. (2010). Rising Youth Unemployment During the Crisis: How to Prevent Negative Long Term Consequences on a Generation? OECD Social, Employmnet and Migration Papers, OECD.

Schwartz, J. Z., Andres, L. A., \& Dragoiu, G. (2009). Crisis in Latin America: Infrastructure Investment, 
Employment and the Expectations of Stimulus. Word Bank Working Paper 5009. https://doi.org/10.1177/097493060900100202

Skoufias, E., \& Parker, S. (2006). Job Loss and Family Adjustments in Work and Schooling During the Mexican Peso Crisis. Journal of Population Economics, 19. https://doi.org/10.1007/s00148-005-0005-3

Sokoloff, K., \& Zolft, E. (2007). Inequality and the Evolution od Institutions of Taxation. In S. Edwards et al. (Eds.), The Decline of Latin American Economies. University of Chicago Press. https://doi.org/10.7208/chicago/9780226185033.003.0004

Stiglitz, J. (2003). El Rumbo de las Reformas: Hacia una Nueva Agenda para America Latina. Revista de la Cepal, 80. https://doi.org/10.18356/46a2a558-fr

Szekely, M., \& Karver, J. (2015). Youth Out of School and Out of Work in Latin America. A Cohort Approach. Working paper number 7421, World Bank, Washington DC. https://doi.org/10.1596/1813-9450-7421

TERCE, Tercer Estudio Regional Comparativo y Explicativo. (2016). Unesco, Santiago de Chile.

TSounta, E. (206). Why are Women Working so Much More in Canada? An International Perspective. Working paper, International Monetary Fund.

\section{Notes}

Note 1. These authors point out that: "The economic crisis caused is a significant loss of jobs particularly among young unskilled workers in the manufacturing industry in the north of the country. The resulting new Neets found themselves without opportunities in the market for legal activities, but with an increasing demand for relatively well paid criminal activities in drug trafficking organizations" (p. 27).

Note 2. See Cerruti (2000), Skoufias and Parker (2006), Parker and Skoufias (2009), Paz (2009). Cáceres (2013) has presented a review of this literature.

Note 3. Youth unemployment comprises the unemployment experienced by the population between 15 and 24 years.

Note 4. World Development Indicators data for the Guatemalan Neets is available only for the 2009-2017 period.

Note 5. These authors point out that: "We emphasize that youth face high costs of churning, or moving from job to job. The working conjecture is that the destruction and creation of jobs seem to have affected the young more adversely than other groups... there is evidence that after trade liberalization, labor market conditions worsened for individuals with low skills and low experience. The jobs created required greater abilities than what the youth could offer" (p. 32).

Note 6. Data on homicides and number of persons incarcerated were taken from UNDP, Human Development Report 2016.

Note 7. Data on 1870 per capita taxes was taken from Sokoloff and Zolft (2007).

Note 8. Ho (2006) cites List (1991) on the importance of building an economy with production capacity that would "Guarantee the existence of the nation future".

Chang (2002) has pointed out that Adam Smith argued in his work: The Wealth of Nations, that the United States should give up protecting their manufacturing industry, since it's comparative advantage was in agriculture and therefore it should aspire to become an agricultural country like those of Eastern Europe. The answer of this country according to Chang (2002) was: "the Americans firmly rejected Smith's analysis in favor of "common sense" and the instinct of what was necessary for the nation" proceeding to protect their infant industries with great success after $1816^{\circ}$. Chang (2002), shows the values established by the United State for the tariffs on imports of goods manufactured between 1820 and 1931, which varied between 40 and 50 percent, to drop to 14 percent in 1950.

\section{Copyrights}

Copyright for this article is retained by the author(s), with first publication rights granted to the journal.

This is an open-access article distributed under the terms and conditions of the Creative Commons Attribution license (http://creativecommons.org/licenses/by/4.0/). 